\title{
Blasts 20-30 Percent of Bone Marrow Nucleated Cells
}

National Cancer Institute

\section{Source}

National Cancer Institute. Blasts 20-30 Percent of Bone Marrow Nucleated Cells. NCI

Thesaurus. Code C146712.

A semi-quantitative microscopic finding indicating that between 20 and 30 percent of the nucleated cells in a bone marrow sample are immature mononuclear cells. 